\title{
A Novel Single Input Double Output (SIDO) Converter for Torque Ripple Minimization in Solar Powered BLDC Motor
}

\author{
Bapayya Naidu Kommula* and Venkata Reddy Kota
}

\author{
Department of Electrical and Electronics Engineering, Jawaharlal Nehru technological University Kakinada, India
}

\begin{abstract}
This paper proposes a new converter topology for torque ripple reduction in Brushless DC (BLDC) motor. Due to the torque ripple problem, the use of this motor is limited to few applications. In this paper, a Single Input Double Output (SIDO) converter is proposed to suppress the torque ripple in BLDC motor. The proposed SIDO converter provides two output voltages. One for supplying the motor throughout conduction time and second output voltage is given to the non-commutating phase of motor during commutation instants. This proposed SIDO converter is fed from Photo Voltaic (PV) system. This paper also presents a new Maximum Power Point Tracking (MPPT) based on trisection of Power-Voltage characteristics (TPVC) to attain the maximum power from the PV system. This scheme takes only 7 iterations to reach MPP. The intended configuration is developed and simulated in Matlab/Simulink environment. The results justify the superiority of proposed scheme that minimizes torque ripple in BLDC motor to only 6 to $12 \%$ from 50 to $80 \%$ in conventional scheme and also extracts maximum power from PV system. C2019. CBIORE-IJRED. All rights reserved
\end{abstract}

Keywords: BLDC motor, Torque Ripple, Single Input Double Output (SIDO) Converter, Maximum Power Point Tracking (MPPT)

Article History: Received: Sep 11, 2017; Revised: October 17, 2018; Accepted: November 18, 2018; Available online: July 15, 2019

How to Cite This Article: Kommula, B. N., Kota, V.R., (2019) A Novel Single Input Double Output (SIDO) Converter for Torque Ripple Minimization in Solar Powered BLDC Motor. Int. Journal of Renewable Energy Development,8(2), 161-168.

https://doi.org/10.14710/ijred.8.2.161-168

\section{Introduction}

Recently, there is momentous gain in the recognition earned by BLDC motor. The BLDC motor is broadly used in many applications such as aerospace, robotics, automobile industry, traction system and medical instruments (Huang et al 2012). These motors have many features like higher power density, compact in size, robust structure, higher torque to weight ratio and smooth control of speed over a wide range (Park et al 2000). The BLDC motor is similar to permanent magnet synchronous motor in construction point of view (Xia et al 2012). The three phase concentric windings are placed on stator and rotor has permanent magnets. This motor is electronically commutated motor which eliminates the sparking problem in which associated with the mechanical commutator (Haines et al 2016). The commutation occurs in this motor is based on the position of rotor. Hall Effect sensors are used to identify the position of rotor position (Li et al 2014)

To achieve the smooth response of the motor without any ripple in torque, the shape of the stator current should be rectangular and it should be in phase with trapezoidal back EMF waveform. But, in practical conditions, the stator current is deviated from its ideal shape because of its inductance effect. This causes ripple in stator current which results the torque ripple in motor (Pahalvani et al 2017). Due to this torque ripple problem,
BLDC motor is unable to use in sensitive applications where smooth response of the motor is essential. Hence, a new control approach is required to suppress the torque ripple. Researchers have proposed various techniques for minimizing the torque ripple. A new converter topology is intended by Welchko et al (2004). However, this topology is used for low speed operation of motor only. In this paper, a novel converter topology is proposed for obtaining the minimal torque ripple. This proposed topology is supplied by PV system.

To generate the electric power, renewable energy sources are extensively used due to the shortage of conventional sources like coal, gas etc. Among various existing renewable sources, solar energy is preferred (Kouro et al 2015). The PV system has many advantages such as less maintenance, noiseless operation and also eco-friendly (Khan et al 2016). The produce power in PV system is mainly assessed based on temperature and atmospheric conditions. According to changes in load and weather conditions, the generated power in PV system is varying. Maximum Power Point (MPP) tracking schemes are effectively used to obtain the maximum power from PV system. Kota et al (2017) and Bhukya et al (2017) are discussed Various MPPT approaches which are differed by each other by its own features. An OCV and SCC approach is proposed by Chowdhury et al (2010) to get the MPP. But, it has high power loss. The most commonly used MPP tracking scheme is PandO

* Corresponding author: kbapayanaaiidu@gmail.com 
technique. However, it cannot ascertain the exact location of MPP and also decreases the MPPT efficiency (Kota et al 2016). This paper proposes a novel MPPT scheme based on trisection of PV characteristics.

These MPPT schemes are applied on dc-dc converters which are used in PV system. Numerous converter topologies are proposed for PV system by Quan et al (2008). To step up the voltage buck converter is used. But, it is not suitable for power factor correction. Boost converter is used to raise the voltage level. However, it could not provide over voltage protection (Gules et al 2014). This paper proposes a novel converter which provides two output voltages from a single input. These two outputs are used to supplying the voltage source inverter (VSI) by using a proper switching selector. This VSI is connected to BLDC motor.

\section{Proposed SIDO Converter Topology}

Fig. 1 shows the block diagram of BLDC motor drive with proposed converter topology for minimizing the torque ripple. The input of proposed Single Input Double Output (SIDO) converter is connected to 200W KC200GT multi crystalline PV system. To track the MPP from this PV system, based on trisection of PV characteristics is used. The proposed SIDO converter provides two output voltages $V_{A}$ and $V_{B}$. In this intended configuration, during conduction and commutation instants the desired voltage is obtained through selection of proper switch that feeds the VSI with right voltage level. This is done by varying the duty cycle of SIDO converter. During normal operation of motor, VSI is connected to first output voltage $\mathrm{V}_{\mathrm{A}}$ of SIDO converter through switch $\mathrm{Q}_{1}$. At the time of commutation, VSI is connected to second output voltage $\mathrm{V}_{\mathrm{B}}$ through switch $\mathrm{Q}_{2}$ in such a way that the rate of change of incoming current and outgoing currents are remains equal. Hence, torque ripple is minimized.

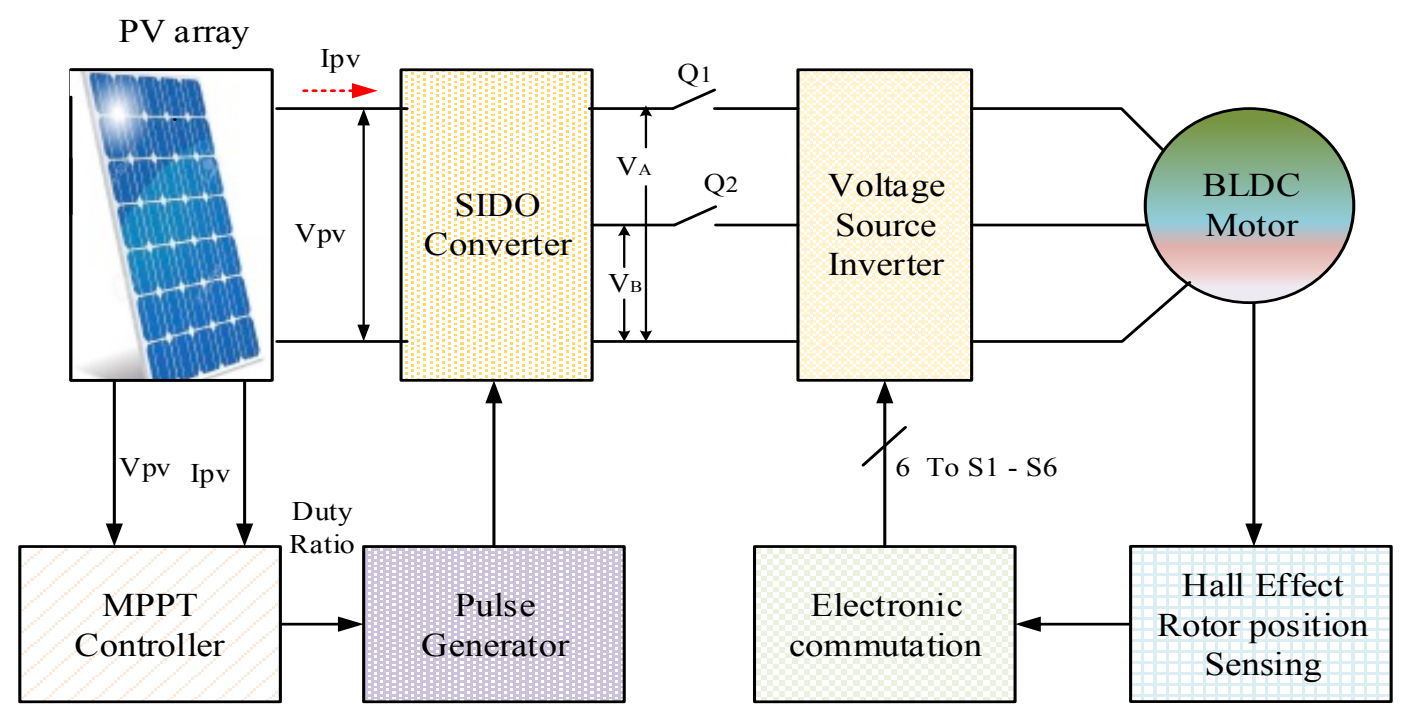

Fig. 1 Basic block diagram of proposed topology

\section{Mathematical modeling of BLDC motor}

The equivalent circuit of BLDC motor is depicted in Fig. 2. Each phase voltage of stator winding is expressed as following below equations during commutation (Jiancheng et al 2013)

At the time of conduction, back EMF is considered to be constant for analysing the commutation torque ripple. Fig.2 depicts the flow of current direction during commutation. Here, phase A current is assumed to be rising, phase $\mathrm{C}$ current is decaying via freewheeling diode and $\mathrm{B}$ is non-commutating phase. Each phase voltage of stator winding is expressed as following below equations during commutation

$$
\mathrm{V}_{\mathrm{an}}=\mathrm{R} \mathrm{i}_{\mathrm{a}}+\mathrm{E}_{\mathrm{a}}+\mathrm{L} \frac{\mathrm{di}_{\mathrm{a}}}{\mathrm{dt}}
$$

$$
\begin{aligned}
& V_{b n}=R_{i_{b}}+E_{b}+L \frac{d i_{b}}{d t} \\
& V_{c n}=R_{i_{c}}+E_{c}+L \frac{d i_{c}}{d t}
\end{aligned}
$$

The torque generated by motor is expressed as follows

$$
\mathrm{T}_{\mathrm{e}}=\frac{\mathrm{e}_{\mathrm{a}} \mathrm{i}_{\mathrm{a}}+\mathrm{ebi}_{\mathrm{b}}+\mathrm{e}_{\mathrm{c}} \mathrm{i}_{\mathrm{c}}}{\omega}=\frac{2 \mathrm{E} \mathrm{I}_{\mathrm{O}}}{\omega}
$$

here, $\mathrm{E}$ denotes magnitude of back EMF, $\mathrm{I}_{0}$ is the magnitude of phase current, $\omega$ is speed of motor. 


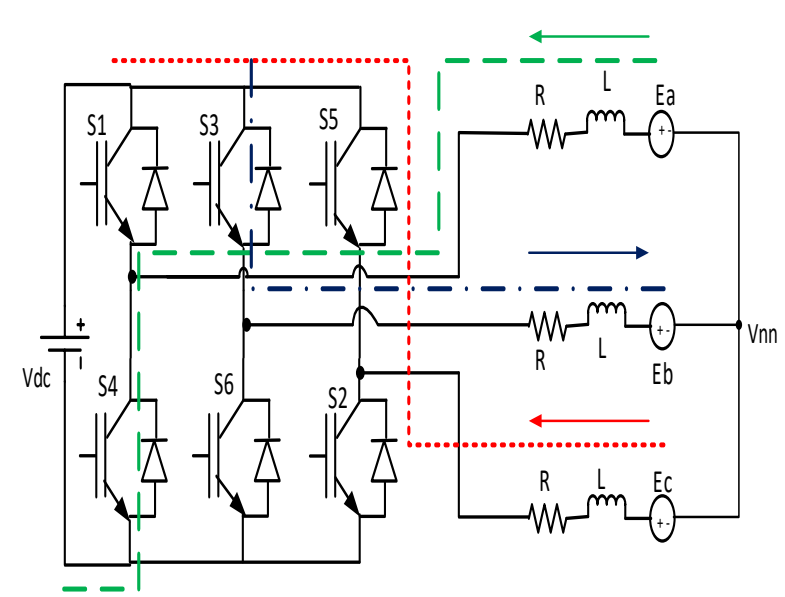

Fig. 2 Direction of current flow during commutation

Phase currents of motor are expressed as follows with negligible voltage drops across switches (Carlson et al., 1992)

$$
\begin{aligned}
\frac{\mathrm{di}_{\mathrm{a}}}{\mathrm{dt}} & =\frac{-2}{3 \mathrm{~L}} \mathrm{Vdc}+\frac{2}{3 \mathrm{~L}} \mathrm{E} \\
\frac{\mathrm{di} b}{\mathrm{dt}} & =\frac{1}{3 \mathrm{~L}} \mathrm{~V}_{\mathrm{dc}}-\frac{4}{3 \mathrm{~L}} \mathrm{E} \\
\frac{\mathrm{di}_{\mathrm{c}}}{\mathrm{dt}} & =\frac{1}{3 \mathrm{~L}} \mathrm{Vdc}_{\mathrm{dc}}+\frac{2}{3 \mathrm{~L}} \mathrm{E}
\end{aligned}
$$

As per the above equations, current in noncommutating phase can be increasing, decreasing or being constant. Hence, at the time of commutation, noncommutating phase has positive slope at lower speed and has negative slope at higher speed. Thus, this slope is recompensed during commutation by injecting an extra voltage into non-commutating phase at both speeds. This voltage is provided by proposed SIDO converter of second output voltage $\mathrm{V}_{\mathrm{B}}$ during commutation instants. In the next following sections. Solar power system and operation of SIDO converter and how can it minimize the torque ripple in motor is described.

\section{The Solar power system}

\subsection{PV system modelling}

Solar panel is a composite of $\mathrm{p}-\mathrm{n}$ semiconductor, it converts light energy or light equivalent energy to electric energy through photovoltaic effect (Chatterjee et al (2011)). Fig. 3 shows equivalent circuit of a single diode PV panel used in the paper. Mathematically, output current of PV panel can be expressed as :

$$
I_{P V}=I_{P G}-I_{D S}\left\{\exp \left(\frac{q\left(V_{P V}+I_{P V} R_{S}\right)}{N_{S} A K T}\right)-1\right\}-\frac{V_{P V}+I_{P V} R_{S}}{R_{S h}}
$$

where $\mathrm{I}_{\mathrm{PV}}$ is output current of PV system (A), $\mathrm{I}_{\mathrm{PG}}$ is photo generated current $(\mathrm{A})$, q is charge of electron $\left(-1.602 \times 10^{\text {- }}\right.$ $19 \mathrm{C}), \mathrm{V}_{\mathrm{PV}}$ is output voltage of $\mathrm{PV}$ system (V), $\mathrm{N}_{\mathrm{S}}$ is number of PV cell in the panel, A is diode ideality factor, $\mathrm{K}$ is Boltzman constant $\left(1.38 \times 10^{-23} \mathrm{~J} / \mathrm{K}\right), \mathrm{T}$ is temperature $\left({ }^{\circ} \mathrm{C}\right), \mathrm{R}_{\mathrm{S}}$ and $\mathrm{R}_{\mathrm{Sh}}$ are series and shunt resistance $(\Omega)$.

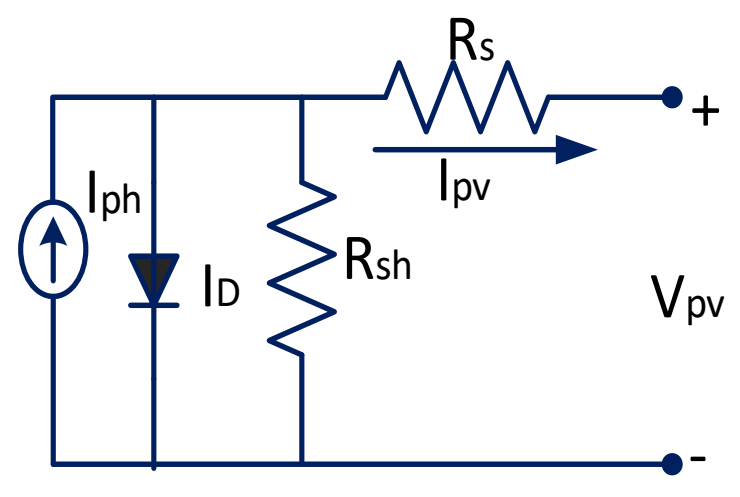

Fig. 3 Single diode PV cell

Photogenerated current ' $\mathrm{IPG}_{\mathrm{PG}}$ ', diode saturation current 'IDS' and reverse saturation current 'Irsc' are given in Eq. (9)- (11).

$$
\begin{aligned}
& I_{P G}=\left(I_{S C, n}+K_{I}\left(T-T_{n}\right)\right) \frac{G}{G_{n}} \\
& I_{O}=I_{r S C}\left(\frac{T}{298}\right)^{3} \exp \left\{\frac{q E_{g}}{A K}\left(\frac{1}{298}-\frac{1}{T}\right)\right\}
\end{aligned}
$$

where

$$
I_{r S C}=\frac{I_{S C, r}}{\left\{\exp \left(\frac{q V_{O C}}{N_{S} K A T}\right)-1\right\}}
$$

where $I_{S C, n}$ is nominal short circuit current (A), $K_{I}$ is current coefficient, $\mathrm{T}_{\mathrm{n}}$ is nominal temperature $\left({ }^{\circ} \mathrm{C}\right), \mathrm{G}$ is irradiance $\left(\mathrm{W} / \mathrm{m}^{2}\right), \mathrm{G}_{\mathrm{n}}$ is nominal irradiance $\left(\mathrm{W} / \mathrm{m}^{2}\right), \mathrm{I}_{\mathrm{rSC}}$ is reverse saturation current (A), $\mathrm{E}_{\mathrm{g}}$ band gap energy (1.3). Table 1 illustrates the specifications of PV panel.

Table 1

AXP-72C-200, 200W PV panel specifications

\begin{tabular}{lcc}
\hline Description & Symbol & Value \\
\hline Maximum power & Pmax & 200.143 \\
Maximum voltage & Vmax & $26.3 \mathrm{~V}$ \\
Maximum current & Imax & $7.5 \mathrm{~A}$ \\
Open circuit voltage & Voc & $32.8 \mathrm{~V}$ \\
Short circuit current & Isc & $8.3 \mathrm{~A}$ \\
\hline
\end{tabular}

\subsection{Proposed MPP Tracker based on Trisection of Power - Voltage Characteristics (TPVC)}

Maximum power point of PV system has to be tracked continuously using MPPT schemes. The existing schemes possess certain demerits as mentioned by (Elbaset et al (2016)). Hence, this paper presents a novel MPP tracker based on TPVC. The proposed MPP tracker trisects the closed search space and continues to iterate until the search space is converged to maximum point. Based on power-voltage characteristics, the closed search space [X, $\mathrm{Y}]$ is decided. From Fig. 4, X and $\mathrm{Y}$ are considered as $\mathrm{X}=0$, and $\mathrm{Y}=\mathrm{V}_{\text {oc. }}$ In the search space two voltages $\mathrm{V} 1$ and $\mathrm{V} 2$ are generated based on equations as given below

$$
\left.\begin{array}{l}
\mathrm{V}_{1}=\mathrm{X}+\frac{(\mathrm{Y}-\mathrm{X})}{3}=0.67 \mathrm{X}+0.33 \mathrm{Y} \\
\mathrm{V}_{2}=\mathrm{Y}-\frac{(\mathrm{Y}-\mathrm{X})}{3}=0.33 \mathrm{X}-0.67 \mathrm{Y}
\end{array}\right\}
$$


Citation: Kommula, B. N., Kota, V.R., (2019) A Novel Single Input Double Output (SIDO) Converter for Torque Ripple Minimization in Solar Powered BLDC Motor. Int. Journal of Renewable Energy Development,8(2), 161-168, doi.org/ijred.8.2.161-168 $\mathrm{P}$ a g e | 164

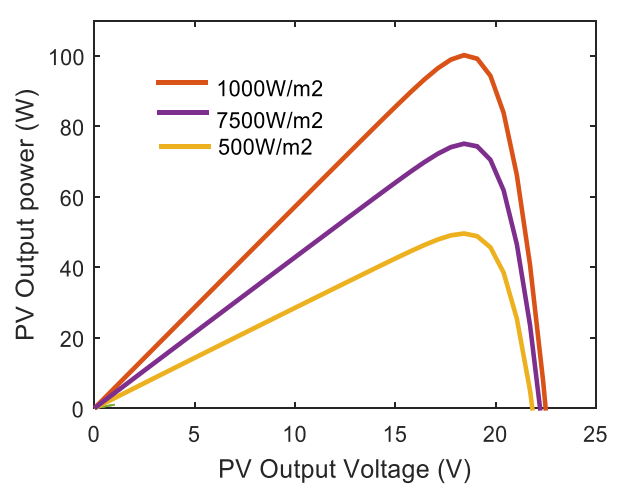

(a)

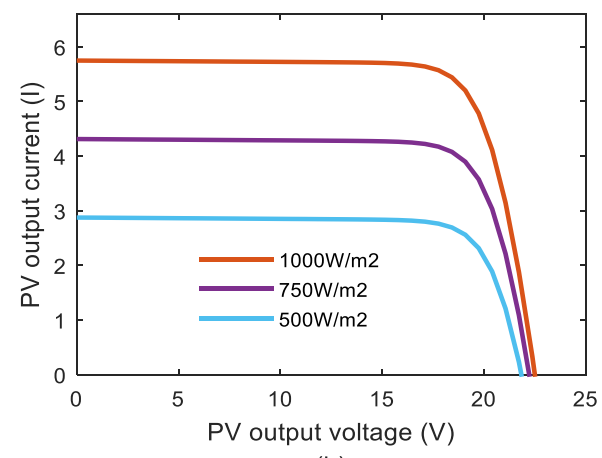

(b)

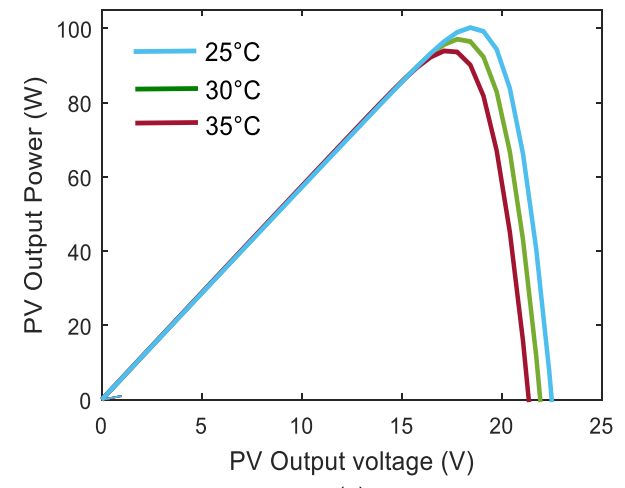

(c)

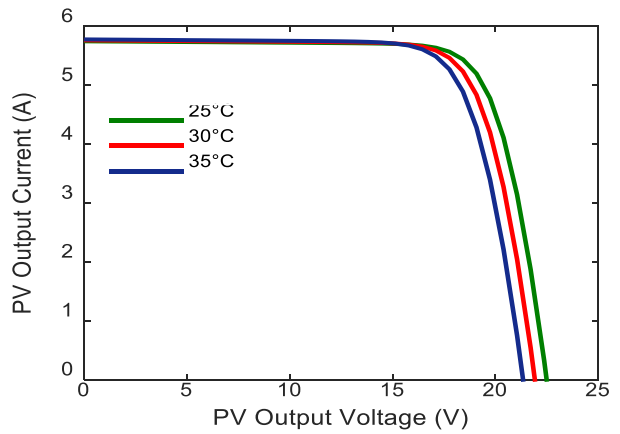

(d)

Fig.4 At constant temperature of $25^{\circ} \mathrm{C}$ (a) P-V and (b) I-V characteristics, At constant irradiance of $1000 \mathrm{~W} / \mathrm{m}^{2}$ (c) $\mathrm{P}-\mathrm{V}$ and (d) I-V characteristics

The powers at these two voltage points $V_{1}$ and $V_{2}$ are sensed as $\mathrm{P}_{1}$ and $\mathrm{P}_{2}$ to decide next search space. If $\mathrm{P} 1>\mathrm{P}_{2}$, the search space is shrunken to $\left[\mathrm{V}_{1}, \mathrm{Y}\right]$ else the space is reduced to $\left[\mathrm{X}, \mathrm{V}_{2}\right]$. Again, the same procedure is continued and search space is trisected until $|\mathrm{P} 2-\mathrm{P} 1|<\varepsilon$ condition is attained. As the search space converged, maximum voltage is obtained at $\mathrm{V}_{\max }=\left(\mathrm{V}_{1}+\mathrm{V}_{2}\right) / 2$. Fig. 5 depicts proposed TPVC flowchart.

The step by step procedure of the MPPT scheme is given below

i. Based on open circuit voltage, select a closed interval [X, Y]

ii. From Eq. (12), voltage at two points $\left(\mathrm{V}_{1}\right.$ and $\left.\mathrm{V}_{2}\right)$ are obtained in the search space

iii. Powers at voltage $V_{1}$ and $V_{2}$ are compared to decide next interval.

If $\mathrm{P}\left(\mathrm{V}_{1}\right)>\mathrm{P}\left(\mathrm{V}_{2}\right)$, the closed interval is updated as $\left[\mathrm{V}_{1}, \mathrm{Y}\right]$ or else $\left[\mathrm{X}, \mathrm{V}_{2}\right]$.

iv. Again, from step (i) to (iii) procedure is repeated

v. Once the condition, $\left|\mathrm{P}_{2}-\mathrm{P}_{1}\right|<\boldsymbol{\varepsilon}$ is attained, the procedure converged to MPP.

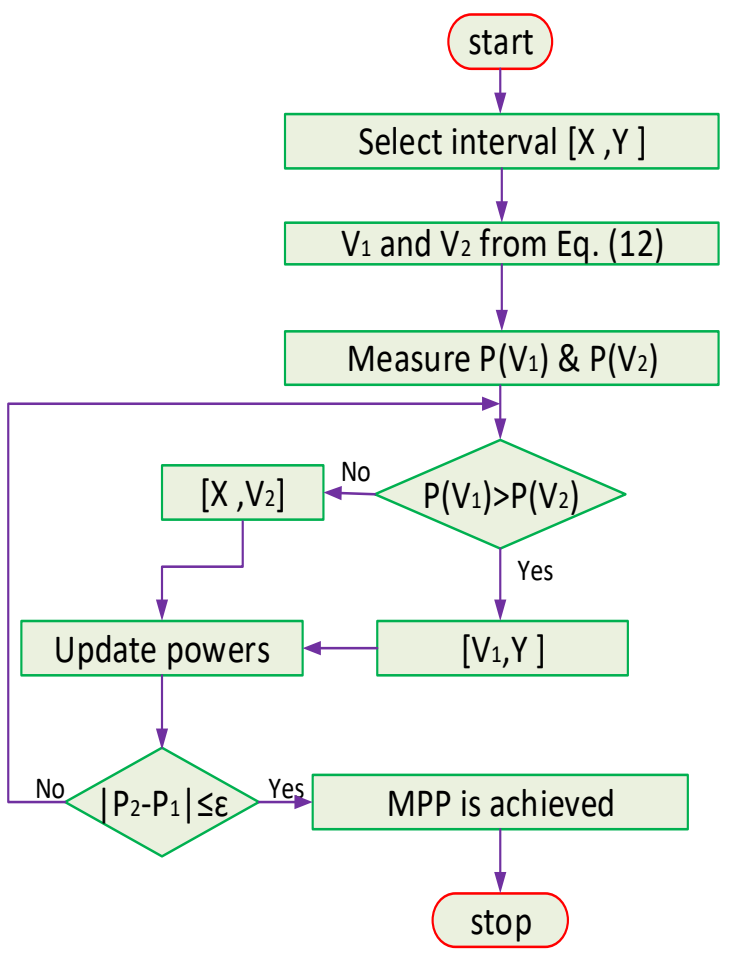

Fig. 5 Proposed TPVC scheme flowchart

\section{Proposed Single Input Double Output Converter}

Fig. 6 depicts the Single Input Double output converter (SIDOC). The parameters of the proposed SIDOC are shown in Table 2. Here, this proposed SIDOC generates two individual output voltage levels from a unique voltage source. This proposed converter contains two switches $\mathrm{Sa}$ and $\mathrm{Sb}$. The operation of this converter is explained in three modes of operation.

Table 2

Parameters of proposed SIDO converter

\begin{tabular}{lc}
\hline Description & Value \\
\hline Input voltage & $28 \mathrm{~V}$ \\
Output voltage $\mathrm{V}_{10}$ & $100 \mathrm{~V}$ \\
Output voltage $\mathrm{V}_{20}$ & $50 \mathrm{~V}$ \\
Inductor La & $12 \mu \mathrm{H}$ \\
Inductor Lb & $8 \mu \mathrm{H}$ \\
Capacitor C1 & $150 \mu \mathrm{F}$ \\
Capacitor C2 & $350 \mu \mathrm{F}$ \\
\hline
\end{tabular}




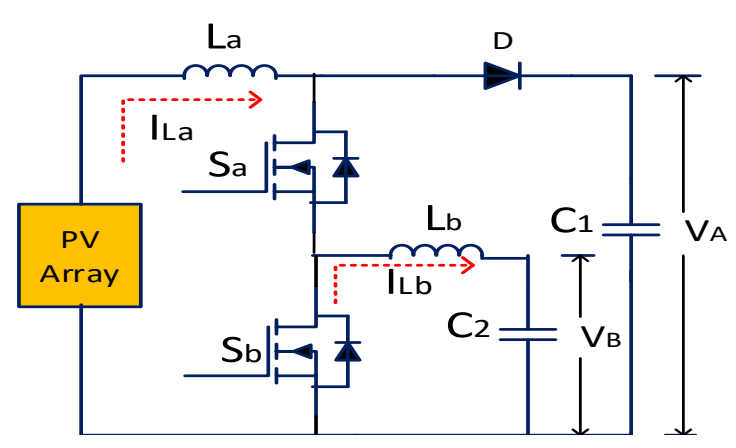

Fig. 6 SIDO converter configuration

Mode I: in this mode of operation, the two switches of converter are in ON state as shown in fig 7(a). The diode $\mathrm{D}$ comes into reverse bias condition. The current $\mathrm{I}_{\mathrm{La}}$ flows through the inductor La while the inductor current $\mathrm{I}_{\mathrm{Lb}}$ freewheels through the switch $\mathrm{Sb}$. The $\mathrm{Dt}_{1}$ represents duty ration in this mode.

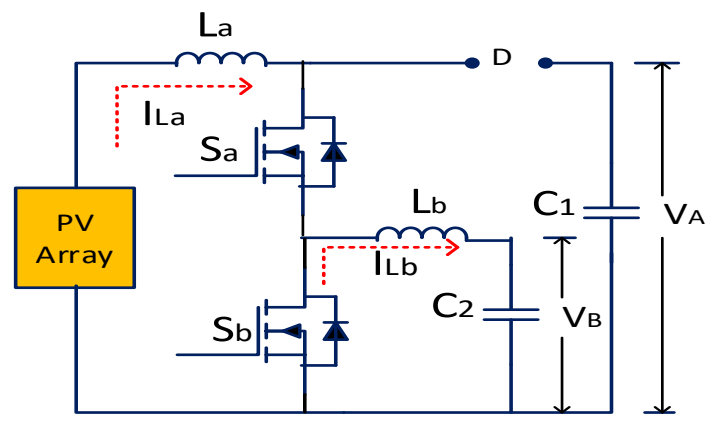

(a)

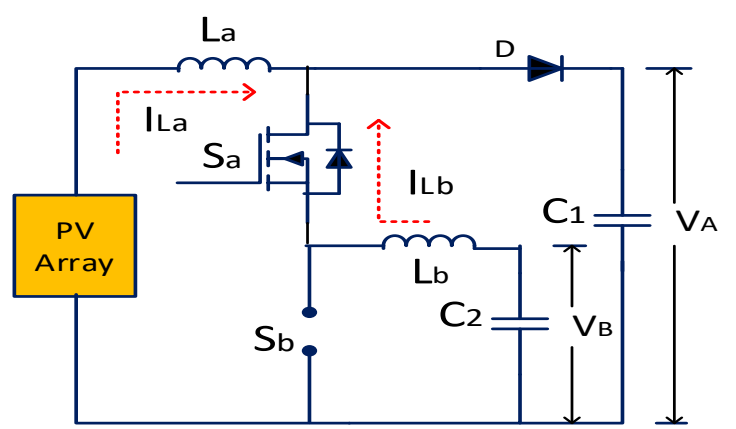

(b)

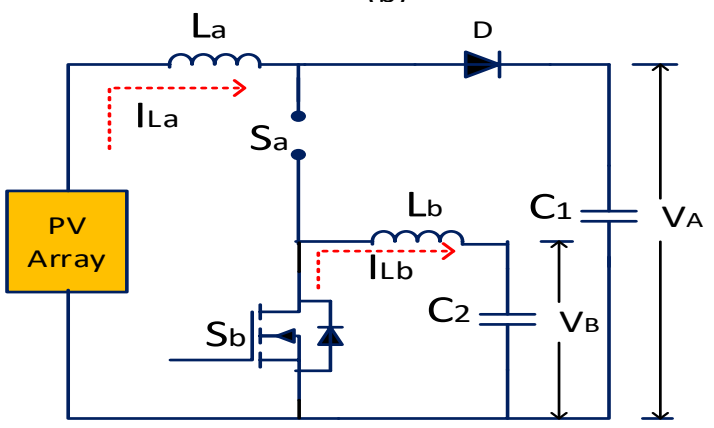

(c)

Fig. 7 operating modes of proposed SIDO converter

Mode II: In this mode, while switch $\mathrm{S}_{\mathrm{a}}$ is in $\mathrm{ON}$ state the switch $\mathrm{S}_{\mathrm{b}}$ is in OFF state as depicted in Fig. 7(b). Here the diode current is equal to the difference between $\mathrm{I}_{\mathrm{La}}$ and $\mathrm{I}_{\mathrm{Lb}}$. The inductor current $\mathrm{I}_{\mathrm{La}}$, flows through the diode
$\mathrm{D}$ and the inductor $\mathrm{L}_{2}$ in this mode. The duty ratio for this mode II is defined as $\mathrm{Dt}_{2}$.

Mode III: During this mode of operation, the switch $\mathrm{S}_{\mathrm{a}}$ is in OFF state and the switch $\mathrm{S}_{b}$ is in OFF state as depicted in Fig. 7(c). In this interval inductor current ILb freewheels through switch $\mathrm{S}_{\mathrm{b}}$. Here, the energy is transferred to their corresponding outputs through the $\mathrm{La}$ and $\mathrm{L}_{\mathrm{b}}$.

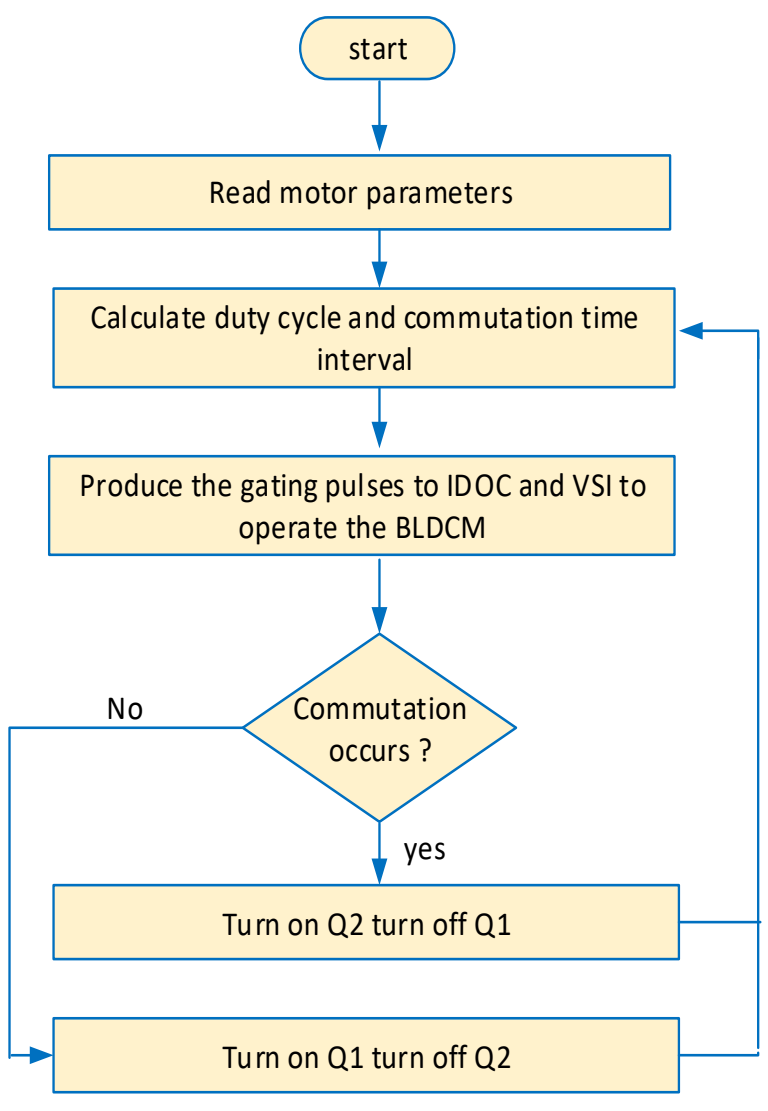

Fig. 8 Flow chart for switch selection of SIDO converter

By employing the respective duty ratios such as $\mathrm{Dt}_{1}$ and $\mathrm{Dt}_{2}$, the two outputs of SIDOC can be regulated. This SIDOC operates in boost mode if the $\mathrm{S}_{\mathrm{a}}$ and $\mathrm{S}_{\mathrm{b}}$ switched on simultaneously. It comes into the buck mode when the $\mathrm{S}_{\mathrm{a}}$ is $\mathrm{ON}$ state and $\mathrm{S}_{\mathrm{b}}$ is OFF state.

For boost operation, the voltage conversion ratio is represented by

$$
\begin{aligned}
& \frac{\mathrm{V}_{\mathrm{A}}}{\mathrm{V}_{\mathrm{dc}}}=\frac{1}{1-\mathrm{D}_{\mathrm{t} 1}} \\
& \frac{\mathrm{V}_{\mathrm{B}}}{\mathrm{V}_{\mathrm{dc}}}=\frac{\mathrm{D}_{\mathrm{t} 2}}{1-\mathrm{D}_{\mathrm{t} 1}}
\end{aligned}
$$

In this intended configuration, during conduction and commutation instants the desired voltage is obtained through selection of proper switch that feeds the VSI with right voltage level. This is done by varying the duty cycle of the SIDO converter. During the conduction interval, the voltage level $\mathrm{V}_{\mathrm{A}}$ is applied throughout to the inverter circuit with respect to the speed and load. At the time of commutation, this intended SIDO converter controls the dc link voltage nearly equal to $4 \mathrm{E}_{\mathrm{m}}$ in such a 
way that the rate of change of incoming and outgoing currents are remains equal. Hence, torque ripple is minimized.

At the time of commutation, the controlled dc voltage and duty cycle are evaluated by the following equation. The output voltage of SIDO converter in boost mode is expressed as

$$
\mathrm{V}_{\mathrm{A}}=\frac{1}{1-\mathrm{D}_{\mathrm{t} 1}} * \mathrm{vdc}
$$

Here, $\mathrm{D}$ represents duty ratio, $\mathrm{V}_{\mathrm{dc}}$ denotes input voltage. To satisfy the condition of $\mathrm{V}_{\mathrm{A}}=4 \mathrm{E}_{\mathrm{m}}$ for duty ratio is given by

$$
\mathrm{D}=\frac{4 \mathrm{ke}_{\mathrm{e}} \omega-\mathrm{vdc}}{4 \mathrm{k}_{\mathrm{e}} \omega}
$$

Fig. 8 depicts the flow chart of the controlled algorithm of BLDC motor with proposed SIDO converter to obtain the minimal torque ripple.

\section{Results and Discussion}

The simulation is done in Matlab/Simulink environment to carry out analysis of the performance of the BDLC motor drive with proposed SIDO converter. The parameters of BLDC motor used for this task is shown in Table 3. The motor is running at a speed of $2000 \mathrm{rpm}$ with an applied load of $1.2 \mathrm{Nm}$. The input line-line voltage of BLDC motor is depicted in Fig. 9.

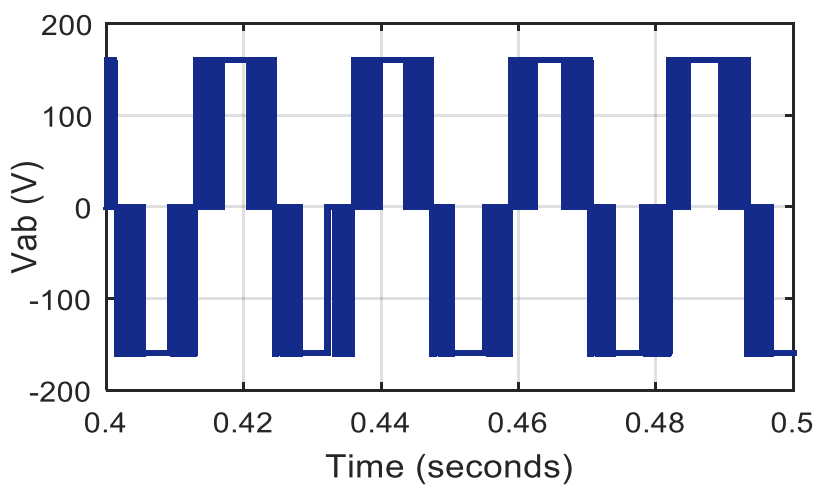

Fig. 9 Input voltage of BLDC motor

The performance of motor by employing traditional control scheme is depicted in Fig. 10. In this conventional control scheme, a Voltage Source Inverter (VSI) which is supplied from Diode Bridge Rectifier (DBR) is connected to BLDC motor. PWM current controller is used to regulate the motor. Phase ' $\mathrm{A}$ ' stator current and back EMF is shown in Fig. 10(a) and (b). Corresponding speed and torque response are illustrated in Fig. 10(c) and (d).

Table 3

Parameters of BLDC motor

\begin{tabular}{lc|}
\hline Description & Value \\
\hline Resistance per phase & $14.56 \Omega$ \\
Inductance per phase & $25.71 \mathrm{mH}$ \\
Rated speed & $2000 \mathrm{rpm}$ \\
Rated Torque & $1.5 \mathrm{Nm}$ \\
No. of poles & 4 \\
\hline
\end{tabular}
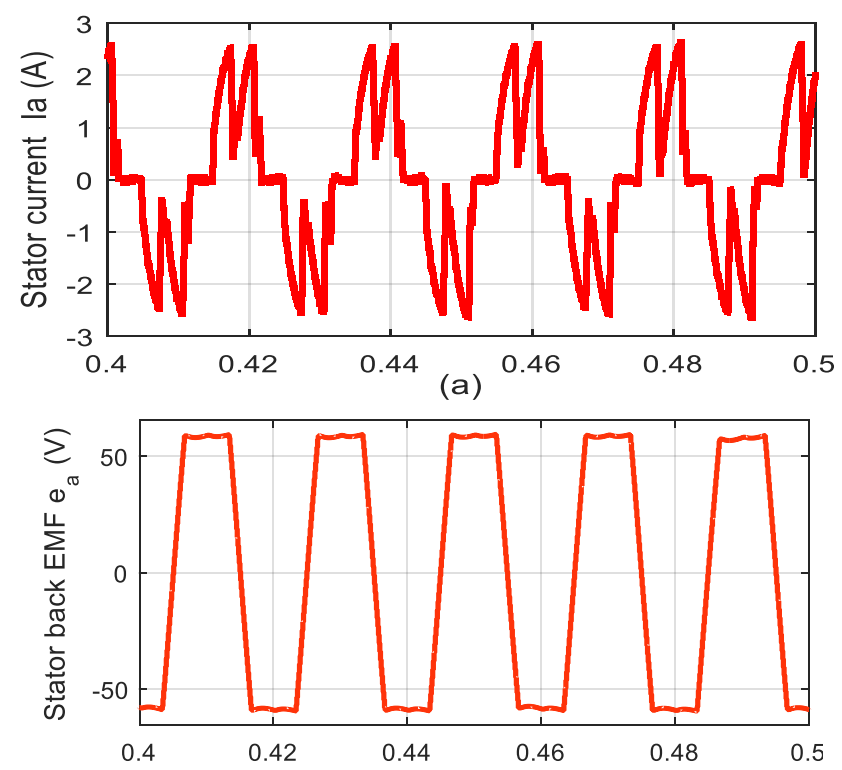

(b)
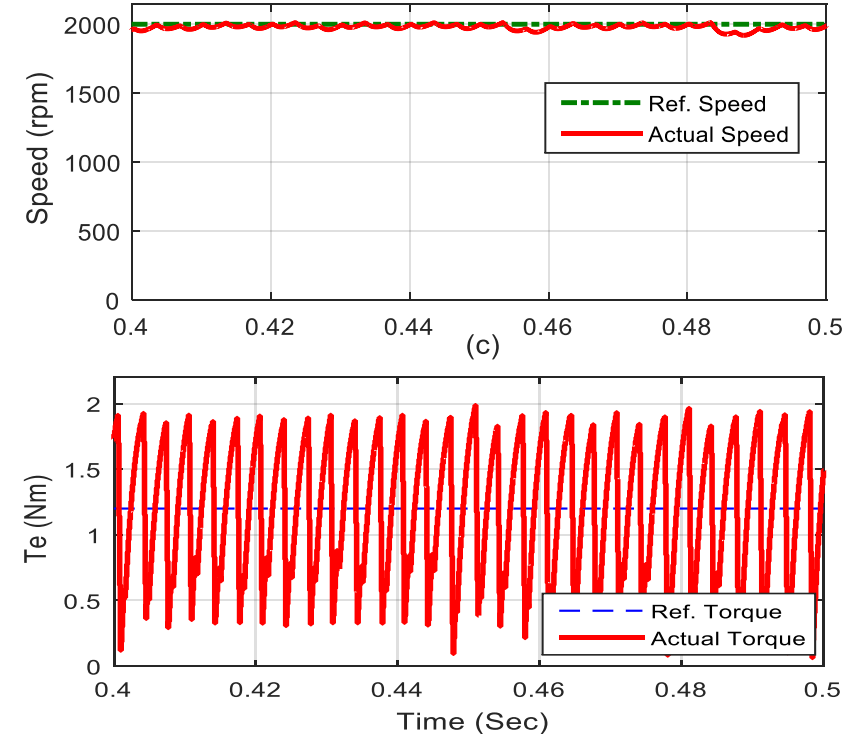

(d)

Fig. 10 (a) stator current (b) back EMF (c) speed (d) Torque with conventional control of BLDC motor

It is cleared from Fig. 10(d), that amount of ripple in commutation torque is high. Hence, to overcome the problem associated with conventional controller, a new topology based on injecting an extra voltage into noncommutation phase of motor during commutation instants is presented in this paper. The proposed SIDO converter gives two independent output voltages. One for continuous operation of BLDC motor and second one is used to reduce the commutation torque ripple by adding it to the non-commutation phase of motor. The proposed MPPT scheme is succeeded in extracting maximum power from AXP-72C-200, 200W panel as shown in Fig. 11(a). At the same time, TPVC scheme has an appreciable convergence towards maximum power point of PV system, which is clearly presented in Fig. 11(b). SIDO converter output voltages $\mathrm{V}_{\mathrm{A}}$ and $\mathrm{V}_{\mathrm{B}}$ are shown in Fig. 11(c). 

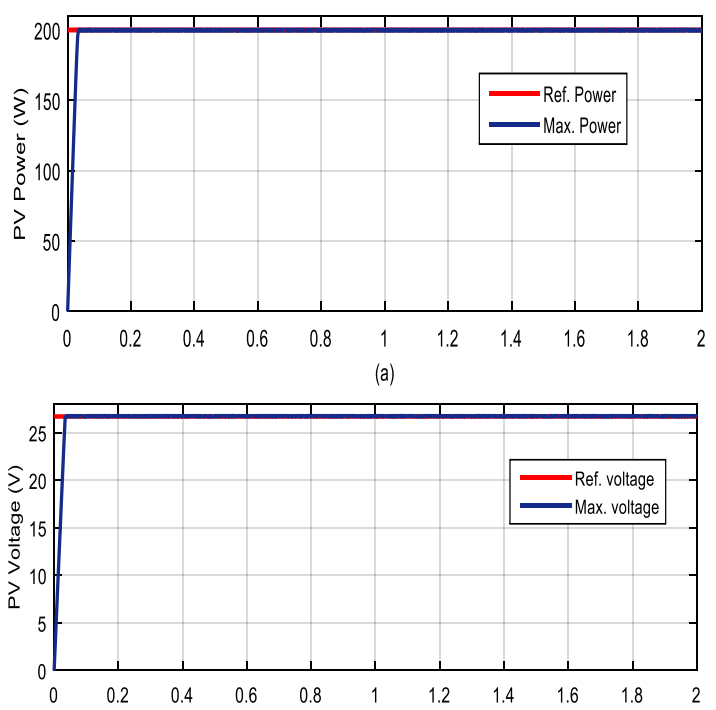

(b)

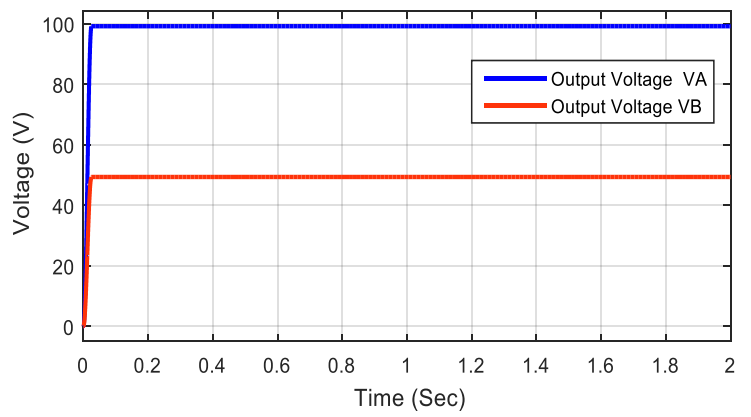

(c)

Fig. 11 (a) Solar PV panel power (b) solar PV voltage (c) Output voltage $V_{A}$ and $V_{B}$ of proposed SIDO converter

The input line to line voltage of BLDC motor with proposed SIDO converter configuration is shown Fig. 12. From this figure, it can be observed that the during commutation instants, voltage is injected from the second output voltage $V_{B}$ of proposed SIDO converter and for continuous operation of motor, voltage is supplied by first output voltage $\mathrm{V}_{\mathrm{A}}$ of SIDO converter which is connected to voltage source inverter of BLDC motor.

The performance of solar powered BLDC motor with proposed SIDO converter topology for torque ripple minimization is depicted in Fig. 13. By employing the proposed scheme, the amount of ripple in stator current is reduced as shown in Fig. 13(a) and also its shape becomes nearer to ideal rectangular shape.

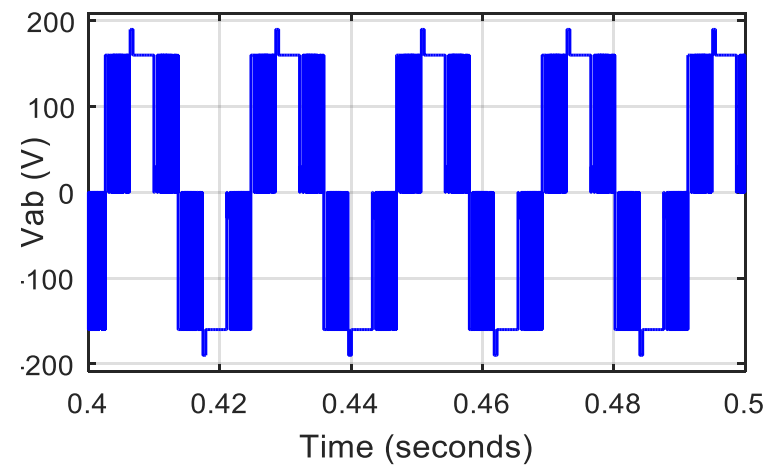

Fig. 12 Input voltage of BLDC motor using proposed method

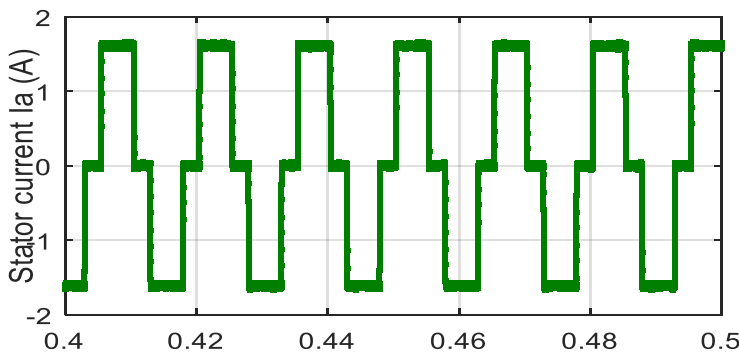

(a)

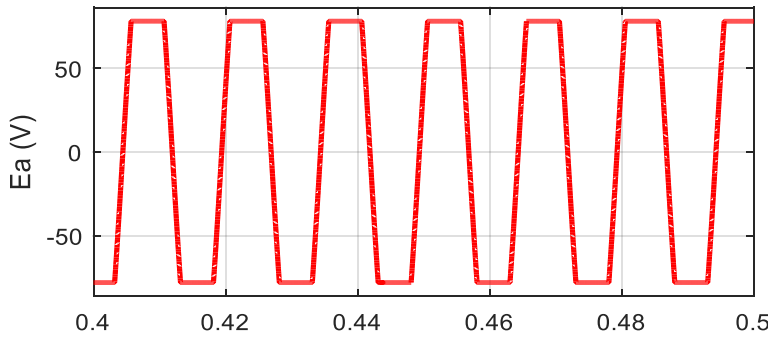

(b)
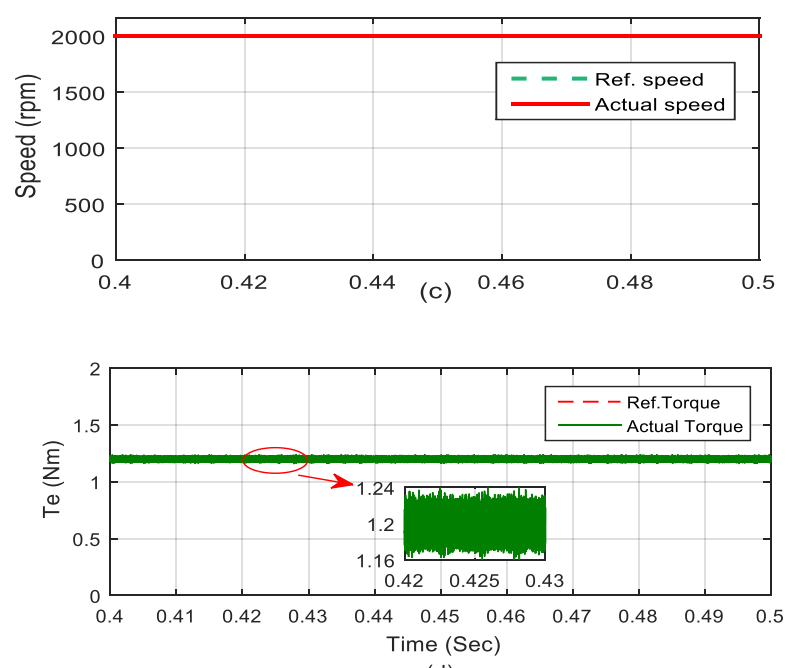

(d)

Fig. 13 (a) stator current (b) Back EMF (c) speed (d) Torque of BLDC motor using proposed SIDO converter
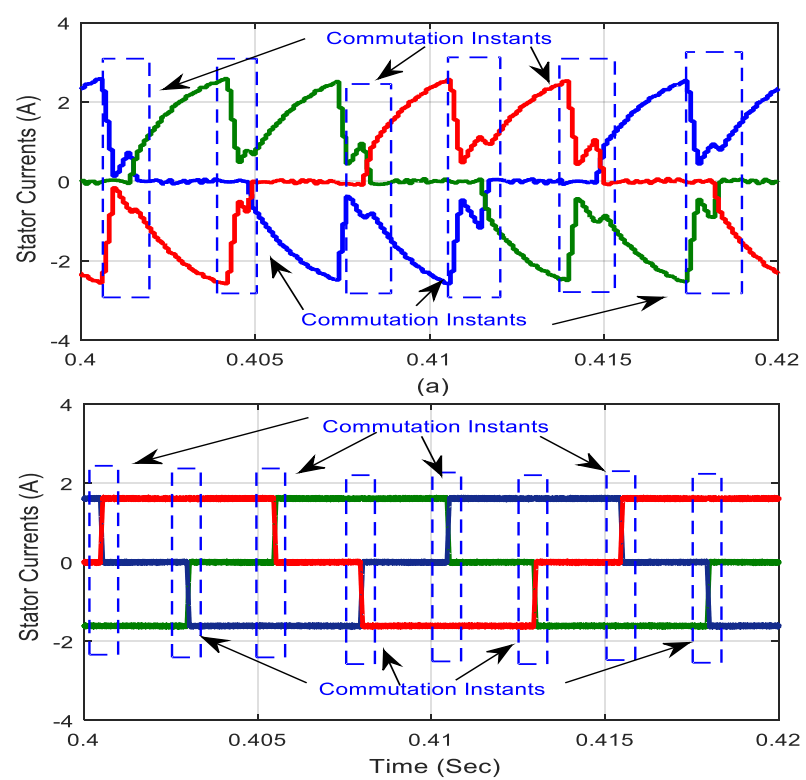

(b)

Fig. 14 Commutation of phase currents in (a) Conventional scheme (b) Proposed scheme 


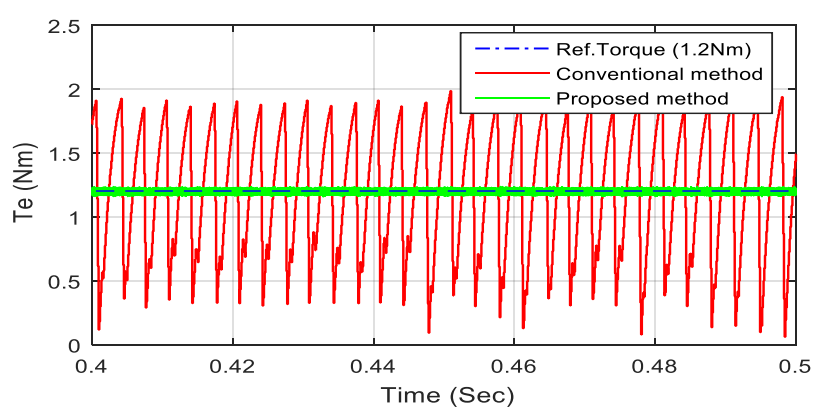

Fig.15 Comparison analysis of proposed scheme with conventional control of BLDC motor

Table 4

Comparison of Torque ripple

\begin{tabular}{cccc} 
Speed & Load & \multicolumn{2}{c|}{ \% Torque Ripple } \\
\cline { 3 - 4 } & Torque & Tonventional & Proposed \\
(Nm) & $\begin{array}{c}\text { Convethod } \\
\text { method }\end{array}$ \\
\hline \multirow{2}{*}{500} & 0.5 & 82.5 & 12.1 \\
& 1 & 78.3 & 8.9 \\
& 1.2 & 76.9 & 7.6 \\
1000 & 0.5 & 77.9 & 10.6 \\
& 1 & 72.5 & 10.2 \\
& 1.2 & 69.3 & 7.3 \\
2000 & 0.5 & 64.5 & 8.3 \\
& 1 & 59.7 & 7.1 \\
& 1.2 & 53.89 & 6.6 \\
\hline
\end{tabular}

\section{Conclusion}

Single Input Double Output based front-end dc-dc converter topology is proposed with an objective of minimizing the torque ripple in a solar powered BLDC motor. During commutation period, the non-commutating phase voltage is increased from $160 \mathrm{~V}$ to $180 \mathrm{~V}$ and torque ripples are reduced. The proposed TPVC scheme effectively extracts maximum power from solar panel. From the results, it is proven that the proposed SIDO converter topology utilizes the solar power efficiently for running the BLDC motor and also effectively curtails the torque ripple at different speeds under variable load conditions.

\section{References}

Bhukya, M.N., Kota V.R. (2017), A Novel PandOT-Neville's Interpolation MPPT Scheme for Maximum PV System Energy Extraction. International Journal of Renewable Energy doi:http://dx.doi.org/10.14710/ijred.0.X.\%p.

Carlson, R., Lajoie-Mazenc, M. and Fagundes. J. C. D. S. (1992), Analysis of torque ripple due to phase commutation in brushless DC machines, IEEE Trans. Ind. Appl., 28(3), $632-638$.

Chatterjee, A., Keyhani, A. and Kapoor, D. (2011), Identification of photovoltaic source models, IEEE Trans. Energy Convers., 26(3), 883-889.

Chowdhary S.R., Hiranmay S. (2010), Maximum power point tracking of partially shaded solar photovoltaic array. Solar energy mater. Sol. Cells, 94:1441-1447.

Elbaset, A.A., Ali, H. and Sattar, M. A.E. (2016), Implementation of a modified perturb and observe maximum power point tracking algorithm for photovoltaic system using an Embedded microcontroller, IET Renew. Power Gener., 10(4):551-560.

Gules, R., Santos, W.M.D., Reis, F.A.D., Romaneli, E.F.R and
Badin, A.A. (2014), A modified SEPIC converter with high static gain for renewable applications, IEEE Trans. Power Electron., 29(11), 5860-5871.

Haines, G., Ertugrul, N. (2016), Wide speed range sensorless operation of brushless permanent magnet motor using flux linkage increment, IEEE Trans. Ind. Electron., 63(7), 40524060.

Huang, X., Andrew, G., Gerada, C., Fang, Y. and Lu, Q. (2012), Design of a five-phase brushless DC motor for a safety critical aerospace application, IEEE Trans. Ind. Electron., 59(9), 3532-3541.

Jiancheng, F., Xinxiu, Z. and Liu, G. (2013), Precise Accelerated Torque Control for Small Inductance Brushless DC Motor, IEEE Transactions On Power Electronics, 28(3): 1400-1412.

Kota V.R., Bhukya, M.N. (2017), A novel linear tangents based PandO scheme for MPPT of a PV system, Renewable and Sustainable Energy Reviews, 71, 257-267.

Kota, V.R., Bhukya, M.N. (2016), A simple and efficient MPPT scheme for PV module using 2-Dimensional look up table, 2016 IEEE Power and Energy Conference at Illinois (PECI), 1-7.

Kouro, S., Leon, J.I., Vinnikov, D., Franquelo, L.G. (2015), An overview of recent research and emerging $\mathrm{PV}$ converter technology, IEEE Trans. Ind. Electron. Mag., 9(1), 47-61.

Khan, J., Arsalan, M.H. (2016), Solar Power Technologies for sustainable electricity generation- A review, Renew. Sustain. Energy Rev, 55, 414-425.

Li, Z., Songfa, Z., Zhou, S. and Ahn J.W. (2014), Torque Ripple Minimization in Direct Torque Control of Brushless DC Motor, J Electr Eng Technol., 9, (5), 1569-1576.

Quan, L., Peter, W. (2008), A Review of the Single Phase Photovoltaic Module Integrated Converter Topologies with Three Different DC Link Configurations, IEEE Trans. Power Electron., 23(3), 1320-1333.

Sheng, T., Wang. X., Zhang, J. and Deng, Z. (2015), TorqueRipple mitigation for brushless DC machine drive system using one-cycle average torque control," IEEE Trans. Ind. Electron., 62(4),2114-2122.

Pahalavani, M.R.A., Ayat, Y.S. and Vahedi, A. (2017), Minimisation of torque ripple in slotless axial flux BLDC motors in terms of design considerations, IET Ele. Power Appl., 11(6), 1124-1130.

Park, S.J, Park, H. W., Lee, M.H., Harashima, F. (2000), A new approach for minimum Torque Ripple Maximum efficiency control of BLDC motor, IEEE Trans. Ind. Electron., 47(1), 109-114.

Viswanathan, V., Jeevananthan, S. (2014), Approach for torque ripple reduction for brushless dc motor based on three-level neutral-point-clamped inverter with dc-dc converter, IET Power Electron., 8(1), 47-55.

Welchko B.A., de Rossiter Correa M. B., and Lipo, T. A. (2004), A three-level MOSFET inverter for low-power drives," IEEE Trans. Ind. Electron., 51(3), 669-674.

Xia, C.L. (2012), Permanent Magnet Brushless DC motor Drives and controls, Singpore: John Wiley andSons pvt. Ltd.

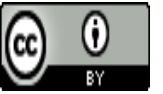

(C) 2019. This article is an open access article distributed under the terms and conditions of the Creative Commons Attribution (CC BY) license (http://creativecommons.org/licenses/by/4.0/). 